\title{
THEORETICAL ANALYSIS OF DEPRECIATION IN MUNICIPALITIES (GNOSIOLOGY, ONTOLOGY AND EPISTEMOLOGY)
}

\author{
D. Velikov* \\ Department of Finance and Management, Plovdiv University "Paisii Hilendarski", Plovdiv, Bulgaria
}

\begin{abstract}
The amortization charge leads to an improvement in the quality of accountability and public finance statistics. Accounting analysis is part of the information function of accounting. The aim of the publication is to analyze depreciation in municipalities and to propose a synthesis of properties and a summary of common features, trends and laws. The ontological nature of depreciation in accounting science presents the main problems solved by accounting for depreciation. Epistemological coverage of depreciation covers its origin, scope and peculiarities. The research methods are analysis and synthesis, comparison, analogy, modeling, systematization and summary, comparative and group accounting analysis. The results obtained are presented in tabular form. The conclusion is that by switching from a smaller range of the signage coverage of the unit to the depreciation in municipalities, we are targeting a wider range of sign coverage, pointing out the qualities of the different categories of depreciation in the municipalities as an internal definition and an external manifestation.
\end{abstract}

Key words: depreciation, theoretical analysis, accounting, public sector, category, quality.

\section{INTRODUCTION}

The accrual of depreciation in the public sector leads to an improvement in the quality of accountability and public finance statistics. The need for accrual of depreciation as a regular reporting process is driven by the demand for sustainability in the public systems. Difficulties in the public sector accounting system arise from accounting treatment and the very nature of the concept of "public good". A typical example of the difficulties faced by the accounting science in the public sector is the development of an informative model in municipalities to account for the depreciation and recovery of fixed assets. For municipalities, the transfer of parts of fixed assets by rescheduling their estimated useful life - as an expense, in the cost price of the product is an

Correspondence to: Diyan Velikov Velikov, Department of Finance and Management, Plovdiv University "Paisii Hilendarski", Plovdiv, 24 Tsar

Asen Str, Tel .: +359878 529847, e-mail:

diyan.velikov@mail.bg expression of the systematic distribution of the depreciable value of the asset over its last life. The subject of the survey is the normative requirements for accruing the depreciation in the municipalities and its subject - accrual and accounting of the depreciation in the public sector.

The origin of the word depreciation comes from the Latin word mortus - dead. The concept of amortization is associated with a lack of functionality for the property. In accounting, depreciation means decreasing the asset's asset value also means 'denial of death' (1) through the reimbursement of the asset from the accumulated amortization. Depreciation is associated with the consumption of fixed assets and, as a result, their depletion, which leads to a decrease in their value. "In accounting terms, amortization reflects the depreciation of fixed assets, accounting for the wastage of fixed capital. "(2) In this sense, under depreciation," we mean "immortalization" of fixed assets through the ability to recover, to be replaced by 
something equally. "(3) Waste of fixed assets leads to a reduction in their value. The reasons for this are mainly two: wear and tear caused by their use in the labor process and aging, which contributes the emergence of new, more sophisticated assets, whose use in the enterprise turns out to be economically more advantageous. Waste is an objective process of loss of consumer properties when using the asset. "For this reason, it is perceived that the value of tangible fixed assets included in the group of depreciable assets should be carried forward by deferring their estimated useful life as an expense in the cost of the product produced in the enterprise by the living human labor. "(4)

The postulates that "... there are different approaches to developing accounting theory, the main among which are a descriptive approach, an empirical approach and a normative approach." (5) enable philosophical research on gnosiology, ontology and epistemology to be used in the study of depreciation. Application find the normative and positive approach in accounting. "In the normative approach, researchers are focused on what accounting data and indicators are required to be presented to consumers and in this context seek the most appropriate reporting of business operations ..." (6) When applying the positive approach, researchers "... attempt to discover and explain the actual relationships and relationships based on empirical observations and inductive conclusions. "(7) The proposed model shown in Table 1 was originally uses the normative approach in accounting. On the basis of the satisfied public needs presented as starting and prime categories, a categorical study has been done and the derived categories are specified by inductive conclusions. In support of our assertions about the use of the positive approach, we can turn to the traditions of the descriptive approach in accounting, which grownds the inductive conclusions. "The accounting theory developed on its basis clarifies the essence of the accounting and analytical work done. The inductive way of knowledge is applied. It consists of making observations for the accounting practice and formulating general conclusions and inferences. "(8) The methods of analysis and synthesis, comparison, analogy, modeling, systematization and generalization are also used. In addition to the general science method, the accounting analysis method is also used, which is a method of investigating the interdependencies within and between accounting entities. The comparative and structural methods were used as methods of accounting analysis. Through the normative approach, priority is given to the deductive-hypothetical beginning, in which the deductive approach is the content and the inductive - the form of control. The starting point is the transition from general and essential circumstances to judgment for the proposed categories in accounting with objective specificity. The contribution of the categorical amortization accounting study is reflected in the generation of new and confirmatory facts about the effect of accounting for amortization in the public sector. On the basis of the described categories of depreciation in municipalities through the positive approach, we give the inductive and hypothetical direction of the analysis by examining their application in the accounting practice by synthesis of properties and generalization of common features, tendencies and laws where the inductive approach is the content and the deductive - the form of control.

Gnosiology of depreciation requires prior clarification of the ontological nature of depreciation in accounting science and its concepts applied to studiy the processes. This is achieved by clarifying the essence of the main categories in accounting and their derivative categories. The latter are the controllable parameters in the amortization plan and amortization policy. Considering depreciation in municipalities we need to clarify the essence of source categories in municipalities as part of the public sector and their derivative categories. Ontology is defined as "a part of philosophy that uses the basic principles, principles, structure, and laws of being." (9) The ontology of depreciation defines it as a process of systematical allocation of the depreciable value as a monetary expression of wastage of fixed assets and as a process, through which the enterprise maintains its property and justifies the renovation of fixed assets. Epistemology (from the Greek Episteme - Knowledge, Logos 
- Teaching) is a philosophical discipline that "observer the stages, the forms and the ralations of the knowledge process as well as criteria for authenticity and truthfulness . "(10) The epistemological analysis of the characteristics of depreciation brings to our attention the path from the theory to the practice and requires consideration of the legal, economic and social aspects of the relevant categories used in the public environment. Epistemological description of depreciation includes its origin, scope and features. If gnosiology reveals the relationship object-subject or, how the knowledge of the object is realized, epistemology reveals the relationship "objectknowledge" ie. what is the knowledge about the structure and features.

Gnosiology "studies the sources, possibilities and means of scientific knowledge; theory of knowledge "(11) and is" ... a category of philosophy and the name of its second level - as a theory of knowledge or a knowledge of knowledge. "(12) It examines the process of knowledge according to the attitude of the subject of knowledge (the researcher) toward the subject of knowledge (the subject being studied) that is the categorical opposition "subject-object". The gnosiologic meaning of depreciation expands the consepts of its ontological nature. Accepting the subjective judgement the researcher offers to the administrator solutions for the epistemological subject - the qualities of accounting for depreciation in municipalities. The obtained frame for amortization is the gnosiological contribution to understanding of how to manage the acquired knowledge.Starting from the internal ralations an external effects is derived concerning the actual state of individual amortization parameters in the municipalities. Taking into account the hierarchical subordination financing of the municipal budget with respect to the state budget and the role of the Ministry of Finance as the controlling authority receiving and managing the financial resources, we should note that the latter has constant managerial impact on the municipality and "... keeping the technological flow of the management processes ... "(13) the budget financing is a management system to the managed system of the municipality. The
VELIKOV D.

accountant works with certain categories. The category is "a notion in the science that expresses the most general and most essential properties and relations between objects and phenomena" (14), "... a basic division by (types, forms) predicates." (15) In the current study we use a combination of categories which extends their significant coverage assuming certain qualities and properties. The communicative nature and meaning of the notions in the auditing and municipal management accounts highlights the depreciation as "... an abstractive accounting-legal category." (16) M. Velkov defines the accounting categories as "financial accounting" (17) and analizes their meanings as "... components not only of the financial management but the general management of the enterprises, acquiring their universal character"(18), and emphasizes their role as "... universal" structural elements "which are the root of accounting ... "(19)

The cause and effect of depreciation, which results in the resilience of certain properties and phenomena to certain pairs of joint notions concepts or categories is carried out by observing the depreciation objects, represented by parameters such as amortization period, amortization amount and others subdivided into categories. Through a critical judgment, using the terms introduced by Immanuel Kant (17241804) a priori and apostate, analytical and synthetic (judgment), a rational position can be assumed for the use of empirical observations and (on the basis of past experience) forming "... synthetic a priori judgments. "(20)

The "amortization" activity in municipalities is carried out through social and economic processes in the public sector. Therefore, the principle of building its categorical system is based on the initial and main categories of the sociology and economy in the public sector and their derivatives. "The difference between the initial and the main category is that the first one determines the substance of social reality, and the second one expresses its forms." (21)

The accounting basis for reporting amortization in municipalities is grounded on the normative requirements for amortization in the public sector set out in a number of official papers such as the State Financial Statistics Manual (GFS2001), the 
United Nations System of Accounts (SNA93) The European System of National Accounts (ESA 95), the Accountancy Act, the National accounting standard (NAS) 4 Depreciation, the NAS 16 Fixed Assets, the NAS 38 Intangible assets, Chart of accounts of the budget organizations, Treasury Department of the Ministry of Finance DDS №20/2004, DDS №14/2013 and DDS №05/2016, Accounting policy and Amortization policy of Municipality.

In order to consider the achievements of standardization accounting, we also take into account the provisions of the International Public Sector Accounting Standards (IPSAS) developed by the International Federation of Accountants (22) The accounting basis for the amortization charge in organizations applied IPSAS' documentation consists of IPSAS 17 Property, plant and equipment, IPSAS 21 Impairment of non - cash assets, IPSAS 26 Impairment of cash generating assets and IPSAS 31 Intangible assets.

By preserving the material and moral qualities of assets, depreciation contributes for the sustainable functioning of the organization. Depreciation is carried out through five processes - allocation of the depreciation value, accounting assesment, expenditure (expence), wear and revenue (income) of the asset potential value. Unlike private, budget organizations consume national income, they do not create a national income what is specific for the revenues of the budget organizations are their target formulation. This revenue represents a deduction from the profit of economic operators in favor of the State, which finances the activity of budget organizations for specific activities and business operations. In results, through the acomplished categorical analysis we obtained classification of depreciation in municipalities shown in Table 1.

A methodological contribution from the categorical survey is found in the appraisal of the amortization requirements for the public sector. The conclusion that can be drawn is that the methods of assessing assets in the public sector need to be improved. The calculation of value in use is complex because of the fact that assets engaged in cash generating activities often include cash flows that are secured in common with other assets. "(23) Complying the public objectives assests that support the performance of activities are often used even though they do not directly bring to any income. Such are the assets available
VELIKOV D.

in structures keeping the public order and safety, health, education, and other structures and in their activities "... it would be necessary to use the replacement value as a substitute for the purposes of financial reporting." (24) The replacement value requires an asset value input to be accounted for depending on the service potential of its use. It is not influenced by market factors and in case of a provisioned or expected decrease of the capacity needed the replacement value also decreases. Improvement in accounting of revaluation and impairment can be achieved by diferentiating into Section 6 "Cost Accounts" a set of accounting records 68 "Negative revaluation accounts". Improvement of revaluation accounting by applying the positive approach in accounting can be achieved by directly taking into account the increase in disposable capital in a newly created revaluation reserve account in Group 10 "Available capital" in Chart of accounts of the budget organizations. This view is supported by the IPSAS 17 philosophy, according to which the revaluation surplus is recognized as a gain or loss (increase or decrease in net assets) at restoration of a decrease from revaluation of the same asset previously recognized as a gain or loss (increase decrease in net assets). We consider that there is a need to overcome the restriction for correspondence between the accounts from group 60 "Costs by Economic Elements" and Group 65 "Expenditures for Acquisition of Assets, Current and Major renovation by economic way" and formation of prime cost through the operational calculation accounts from the group 61 "Expenditure on activity" through inclusion in Chart of accounts of the budget organizations. This will allow the accomplishment of a correct calculation and improvement of the competitiveness of the public sector. In view of the intended purpose and the manner of formation of the depreciation values, it may be reasonable to form the depreciation fund from the budget organizations in the accounts 241 and 242 of the Chart of accounts of the budget organizations. We believe it is appropriate to include a classification in National accounting standard 36 "Impairment of Assets" that separetes the setting of non financial fixed assets as cash generating and non cash assets. We consider that a National accounting standard "Segment Reporting " should be developed with a public sector application. 
VELIKOV D.

Table 1.

\begin{tabular}{|c|c|c|c|c|c|}
\hline $\begin{array}{l}\text { Depart- } \\
\text { ment }\end{array}$ & \multicolumn{5}{|c|}{ Social Sciences } \\
\hline \multirow[t]{18}{*}{$\begin{array}{l}\text { Cate- } \\
\text { gory }\end{array}$} & Output Categories & $\begin{array}{l}\text { Derivative } \\
\text { Categories }\end{array}$ & Qualities & $\begin{array}{c}\text { Internal } \\
\text { Definitiveness }\end{array}$ & External Efect \\
\hline & $\begin{array}{l}\text { Security, } \\
\text { Production and } \\
\text { Distribution }\end{array}$ & Public Sector & $\begin{array}{c}\text { Defense, } \\
\text { Competitivenes, } \\
\text { Social Affairs, } \\
\text { Taxes }\end{array}$ & $\begin{array}{l}\text { Internal Order, } \\
\text { Legislation, } \\
\text { Financing }\end{array}$ & $\begin{array}{c}\text { Defense, Laws, } \\
\text { Pensions, Grants, } \\
\text { Subsi-dies, Compen- } \\
\text { sations }\end{array}$ \\
\hline & $\begin{array}{l}\text { Decentralization, } \\
\text { local self-govern- } \\
\text { ment and local } \\
\text { administration, } \\
\text { costs and revenues } \\
\text { of local authorities }\end{array}$ & Municipality & $\begin{array}{l}\text { Localization, } \\
\text { Defense, } \\
\text { Competitivenes, } \\
\text { Social, Taxation }\end{array}$ & $\begin{array}{l}\text { Financing, } \\
\text { functions }\end{array}$ & Credit, activities \\
\hline & Financing & Budget & $\begin{array}{l}\text { Legality, } \\
\text { expediency }\end{array}$ & $\begin{array}{c}\text { Part of the state } \\
\text { budget }\end{array}$ & Achieving goals \\
\hline & $\begin{array}{c}\text { Non- } \\
\text { Competitiveness - } \\
\text { Competitiveness } \\
\text { Inclusion - } \\
\text { Exclusion } \\
\end{array}$ & $\begin{array}{l}\text { Public clean } \\
\text { welfare }\end{array}$ & $\begin{array}{l}\text { High access, } \\
\text { awareness, } \\
\text { delivery control }\end{array}$ & $\begin{array}{l}\text { Sustainability, } \\
\text { Growth, } \\
\text { Satisfied Needs, } \\
\text { Breathing }\end{array}$ & $\begin{array}{l}\text { Security, Justice, } \\
\text { Food, Drugs }\end{array}$ \\
\hline & $\begin{array}{c}\text { Exclusion, } \\
\text { indivisibility and } \\
\text { uncompetitive } \\
\text { consumption }\end{array}$ & $\begin{array}{l}\text { Public mixed } \\
\text { welfare }\end{array}$ & $\begin{array}{l}\text { Right to choose } \\
\text { consumer and } \\
\text { supplier }\end{array}$ & $\begin{array}{l}\text { Movement, } \\
\text { tourism, leisure }\end{array}$ & $\begin{array}{l}\text { Cable TV, cine-ma, } \\
\text { streets, sidewalks }\end{array}$ \\
\hline & Main categories & $\begin{array}{l}\text { Derivative } \\
\text { categories }\end{array}$ & Qualities & $\begin{array}{c}\text { Internal } \\
\text { definition }\end{array}$ & External effect \\
\hline & $\begin{array}{l}\text { Depreciation, } \\
\text { distribution, } \\
\text { renewal }\end{array}$ & Depreciation & $\begin{array}{l}\text { Stores the value } \\
\text { over time }\end{array}$ & Corrective & $\begin{array}{l}\text { Allocation of the } \\
\text { depreciation value, } \\
\text { accounting } \\
\text { assesment, } \\
\text { expenditure, wear } \\
\text { and revenue of the } \\
\text { asset potential value }\end{array}$ \\
\hline & Owned assets & $\begin{array}{l}\text { Depreciable } \\
\text { assets }\end{array}$ & Control & $\begin{array}{l}\text { Owned assets of } \\
\text { the enterprise } \\
\text { rather than the } \\
\text { owner }\end{array}$ & $\begin{array}{l}\text { Inventory book, } \\
\text { inventory number }\end{array}$ \\
\hline & $\begin{array}{c}\text { Usability as } \\
\text { intended, } \\
\text { Refunds } \\
\end{array}$ & $\begin{array}{l}\text { Expiration date } \\
\text { and useful life }\end{array}$ & $\begin{array}{l}\text { Applicable } \\
\text { utility }\end{array}$ & Time to use & Place to use \\
\hline & $\begin{array}{c}\text { Difference between } \\
\text { initial and residual } \\
\text { state }\end{array}$ & Amortized cost & Distributability & $\begin{array}{l}\text { Distribution } \\
\text { basis }\end{array}$ & $\begin{array}{l}\text { Qualities needed for } \\
\text { activities }\end{array}$ \\
\hline & Distribution & Depreciation rate & Standardization & Controllability & $\begin{array}{l}\text { Instrument norm, } \\
\text { percentage }\end{array}$ \\
\hline & $\begin{array}{l}\text { Expenses for the } \\
\text { period }\end{array}$ & $\begin{array}{l}\text { Amortization } \\
\text { quota }\end{array}$ & Objectivity & Methodology & Value \\
\hline & $\begin{array}{l}\text { Withdrawal from } \\
\text { use }\end{array}$ & Residual value & Net value & $\begin{array}{l}\text { Significant } \\
\text { value }\end{array}$ & $\begin{array}{l}\text { Net book value minus } \\
\text { liquidation costs }\end{array}$ \\
\hline & Entry value & Book value & Historical cost & $\begin{array}{l}\text { Accountancy } \\
\text { cost }\end{array}$ & $\begin{array}{l}\text { Historical cost, } \\
\text { revalued amount }\end{array}$ \\
\hline & Current value & Carrying value & Adjustmen & $\begin{array}{l}\text { Net book value } \\
\text { is accounted for }\end{array}$ & Net value \\
\hline & $\begin{array}{l}\text { Replacement of a } \\
\text { current asset }\end{array}$ & $\begin{array}{l}\text { Replacement } \\
\text { value }\end{array}$ & $\begin{array}{l}\text { Observeable, } \\
\text { depending on } \\
\text { the entity }\end{array}$ & Input value & $\begin{array}{c}\text { The potential for use } \\
\text { of the asset }\end{array}$ \\
\hline & Recovery & $\begin{array}{l}\text { Recoverable } \\
\text { value }\end{array}$ & $\begin{array}{l}\text { Recovery useful } \\
\text { life and potential } \\
\text { of the economic } \\
\text { benefit of the } \\
\text { asset }\end{array}$ & Output & $\begin{array}{l}\text { Difference between } \\
\text { net asset value and } \\
\text { value in use }\end{array}$ \\
\hline
\end{tabular}




\begin{tabular}{|c|c|c|c|c|c|}
\hline & Depreciation & $\begin{array}{c}\text { Depreciation } \\
\text { expense }\end{array}$ & $\begin{array}{c}\text { Accountability, } \\
\text { comparability }\end{array}$ & Accountability & $\begin{array}{c}\text { Accumulation of } \\
\text { value }\end{array}$ \\
\hline Corrective & $\begin{array}{c}\text { Accrued } \\
\text { amortization }\end{array}$ & $\begin{array}{c}\text { Accumulated } \\
\text { value }\end{array}$ & $\begin{array}{c}\text { Potential } \\
\text { qualities }\end{array}$ & Depreciation fund \\
\hline & Corrective & Revaluation & $\begin{array}{c}\text { Subsequent } \\
\text { measurement, } \\
\text { measurement }\end{array}$ & $\begin{array}{c}\text { Understated or } \\
\text { inflated balance } \\
\text { value }\end{array}$ & $\begin{array}{c}\text { Revaluation increase } \\
\text { or decrease }\end{array}$ \\
\hline & $\begin{array}{c}\text { Adjustment, loss } \\
\text { public sector }\end{array}$ & Impairment & $\begin{array}{c}\text { Subsequent } \\
\text { measurement, } \\
\text { accounting } \\
\text { assesment, }\end{array}$ & $\begin{array}{c}\text { Excess of the } \\
\text { carrying amount } \\
\text { over the } \\
\text { recoverable } \\
\text { amount }\end{array}$ & $\begin{array}{c}\text { Loss from holding } \\
\text { the asset }\end{array}$ \\
\hline
\end{tabular}

\section{CONCLUSION}

The proposed model of gnosiological knowledge offers the opportunity to standardize the procedural vision of the cognitive process of the depreciation and form a technological foundation with gnosiologyical significance in the contemporary research process. The scope of observations is widered starting from smaller coverage, taking into account the amortization in municipalities, keeping the unity between form and content in the research and targeting a broad coverage of the issue, pointing out the qualities of the different categories of depreciation in municipalities as internal definition and external effect.

\section{ACKNOWLEDGEMENT}

I would like to thank Assoc. Prof. Nikolay Penev, $\mathrm{PhD}$ presenting this paper at the conference, which I was hindered from attending.

\section{REFERENCES}

1. Svrakov A., B. Brezoeva, B. Kostov, V. Filipov, M. Tsvetanova, N. Rizov, Accounting: 2018, Trud and Law, Sofia, 2018, pp. 602-603.

2. Bonev, G., Depreciation of Fixed Assets, Informa-Intellect, Sofia, 1996, p. 9.

3. bid, p. 10.

4. Dushanov, I., M. Dimitrov, Company Accounting Course, Trakia M, Sofia, 2016, p. 130.

5. Trifonov, T., Theory of Accounting, Stopanstvo, Sofia, 1997, p. 42.

6. Georgieva, D., The Applicable Base of Public Sector Accounting, Economic Thought Magazine, Sofia, 2016, p. 5, p. 51.

7. Ibid, p. 51.

8. Trifonov, T., Theory of Accounting, Stopanstvo, Sofia, 1997, p. 43.

9. Dictionary of Bulgarian Language, Institute for Bulgarian Language, Bulgarian Academy of Sciences, AI "Prof. Marin Drinov ", Glossary of Bulgarian language, last visited on 02.05.2019.
10. Ibid, last visited on 02.05.2019.

11. Ibid, last visited on 02.05.2019.

12. Arnaudov, I., Nikolay Hristov, Stefan Michev, A Short Dictionary of the Humanitarian Knowledge, Litavra, Sofia., 1994, p. 39.

13. Hristov, S., Organization of Management and Design of Construction Management Systems, ed. Georgi Bakalov, Varna, 1982, p. 20.

14. Dictionary of Bulgarian Language, Institute for Bulgarian Language, Bulgarian Academy of Sciences, AI "Prof. Marin Drinov ", Glossary of Bulgarian language, last visited on 02.05.2019.

15.Polikarov, A., Philosophical Odyssey, AI "Prof. Marin Drinov ", Sofia, 1999, p. 50.

16. Svrakov A., B. Brezoeva, B. Kostov, V. Filipov, M. Tzvetanova, N. Rizov, Accounting: 2018, Trud and Law, Sofia, 2018, p. 344.

17. Velkov, M., Commentary on the Application of International Accounting Standards, "APIS - Romil Kolev", Sofia, 2002, p. 37.

18. Ibid, p. 37.

19. Ibid, p. 38.

20.Polikarov, A., Philosophical Odyssey, AI "Prof. Marin Drinov ", Sofia, 1999, p. 170.

21. Bliznakov, Petko, Introduction to Sociology, Varna Free University, Varna, 1996, p. 66.

22.www.ifac.org (2019) Handbook of International Public Sector Accounting Pronouncements, 2018, IFAC, Volume 1, p. 106 - 107. [online] Available at: https://www.ifac.org/system/files/publications /files/IPSASB-HandBook-2018-Volume1.pdf [Посетен на 26.04.2019].

23. Ibid, p. 118. [Посетен на 26.04.2019].

24. Ibid, p. 118. [Посетен на 26.04.2019]. 